\title{
Short-Term Effects of Spent Mushroom Substrate Mulching Thickness on the Soil Environment, Weed Suppression, Leaf Nutrients, and Nut Characteristics in a Hazelnut Orchard
}

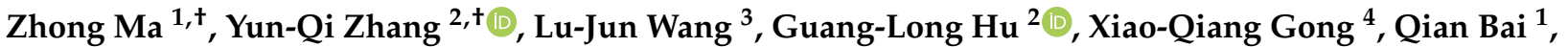 \\ Shu-Chai Su ${ }^{1, * \mathbb{D}}$ and Jian-Xun $\mathrm{Qi}^{2, *}$
}

1 The Key Laboratory for Silviculture and Conservation of the Ministry of Education, Beijing Forestry University, Beijing 100083, China; mazhong@bjfu.edu.cn (Z.M.); baiqian0219@bjfu.edu.cn (Q.B.)

2 Beijing Academy of Forestry and Pomology Sciences, Beijing 100093, China; zhyq1985@bjfu.edu.cn (Y.-Q.Z.); hglcau@gmail.com (G.-L.H.)

3 Anhui Academy of Forestry, Hefei 230031, China; wanglujun1984@126.com

4 State Key Joint Laboratory of Environmental Simulation and Pollution Control, School of Environment, Tsinghua University, Beijing 100084, China; gongxiaoqiang@126.com

* Correspondence: sushuchai@sohu.com (S.-C.S.); qijx@263.net (J.-X.Q.)

+ These authors contributed equally to this work.

Citation: Ma, Z.; Zhang, Y.-Q.; Wang, L.-J.; Hu, G.-L.; Gong, X.-Q.; Bai, Q.; Su, S.-C.; Qi, J.-X. Short-Term Effects of Spent Mushroom Substrate Mulching Thickness on the Soil Environment, Weed Suppression, Leaf Nutrients, and Nut Characteristics in a Hazelnut Orchard. Agronomy 2021, 11, 1122. https:// doi.org/10.3390/agronomy11061122

Academic Editor:

Antonios Chrysargyris

Received: 6 April 2021

Accepted: 27 May 2021

Published: 31 May 2021

Publisher's Note: MDPI stays neutral with regard to jurisdictional claims in published maps and institutional affiliations.

Copyright: (c) 2021 by the authors. Licensee MDPI, Basel, Switzerland. This article is an open access article distributed under the terms and conditions of the Creative Commons Attribution (CC BY) license (https:// creativecommons.org/licenses/by/ $4.0 /)$
Abstract: Worldwide, a huge amount of solid fermented waste is produced every year during mushroom production. The rational utilization of spent mushroom substrate (SMS) is conducive to environmental protection and the sustainable development of agriculture. The aims of this work were to analyze the effects of the SMS mulching thickness on the soil environment, weed suppression, leaf nutrients, and nut traits in a hazelnut plantation and provide a theoretical basis for the scientific and reasonable utilization of SMS. An SMS mulching experiment with four mulching thickness treatments (MT1: $5 \mathrm{~cm}$, MT2: $10 \mathrm{~cm}$, MT3: $15 \mathrm{~cm}$, and CK: $0 \mathrm{~cm}$ ) was conducted in a semi-arid area of North China in 2019. The soil properties, weed control efficiency, leaf nutrient content, and nut yield and quality characteristics of these treatments were all measured and analyzed. The results showed that (1) the average soil temperatures of MT2 and MT3 at different soil depths were 0.73-1.78 ${ }^{\circ} \mathrm{C}$ and $1.18-2.50{ }^{\circ} \mathrm{C}$ lower than when no mulch was used in warm weather and 0.67$1.05^{\circ} \mathrm{C}$ and $0.99-1.56{ }^{\circ} \mathrm{C}$ higher than when no mulch was used in cold weather. The average soil moisture content of MT1, MT2, and MT3 at different soil depths was $6.27-8.13 \%, 10.66-17.23 \%$, and 7.26-12.81\% higher than that of CK, respectively. There were no significant differences in the soil bulk density or porosity among the four treatments. The average soil nutrient contents (soil organic matter and available N, P, and K) of MT1, MT2, and MT3 were 7.05-15.23\%, 14.90-38.93\%, and $17.42-40.11 \%$ higher than those of $C K$, respectively. Soil enzymatic activities of these treatments followed the order MT3 $\approx$ MT2 $>$ MT1 $>$ CK. (2) MT2 and MT3 both had high levels of weed control efficiency: $55.66-92.93 \%$ and $70.43-97.90 \%$, respectively. (3) The leaf N, P, K, and SPAD increased significantly under MT2 and MT3 by about 10\% compared with the CK. (4) MT2 effectively increased the nut size, nut and kernel mass, and crude fat content of the nut (CFC). In general, the short-term field experiment clearly showed that SMS is a superior mulching material for improving the soil environment and plant growth, and $10 \mathrm{~cm}$ thickness is suitable for mulching practice.

Keywords: spent mushroom substrate; mulching measures; soil properties; weed control; nut traits

\section{Introduction}

The genus Corylus L. (hazelnut) includes about 20 species that are widely distributed among temperate regions of Asia, Europe, and North America. It is regarded as one of the most prevalent nut crops in the world. According to the FAO statistics from 2017, the total production of in-shell hazelnuts worldwide exceeded 1 million tons, and the main world producers were Turkey (675,000 t), Italy (131,281 t), Azerbaijan (43,000 t), USA 
$(29,030 \mathrm{t})$, and China (27,044 t) [1]. Hazelnut is a nutrient-dense food owing to its rich concentrations of protein and oil. In addition, hazelnut provides appreciable amounts of sterols, tocopherols, polyphenols, essential minerals, and B-complex vitamins [2]. Owing to its pleasant nutty taste and flavor, hazelnut is widely used for confectionery and bakery products [3]. In recent years, hazelnut planting has been vigorously developed in China, mainly in North China and Northeast China. Although the planting area and yield have increased rapidly, outstanding problems (improper agricultural management, seasonal drought stress, soil degradation, and so on) still restrict the development of the planting industry.

Many studies have shown that mulching is an effective strategy for soil management as it improves the tillage quality by increasing the soil's biological activity, regulating the soil temperature, controlling weed growth, reducing soil evaporation, and preventing nutrient leaching [4]. It also provides benefits for growth, annual and perennial yield, and the health of plants, and its low cost makes it a widespread technique. Different mulching methods and materials have different effects on soil properties and plant growth. A meta-analysis was conducted based on 266 peer-reviewed publications from China, and the results showed that black film mulching is more favorable to crop growth and an increase in the crop yield and water use efficiency (WUE) in arid areas [5]. However, in the long term, the application of plastic film may cause serious soil pollution, and hence have negative effects on crop production [6]. Compared with inorganic mulches, organic mulching could have more benefits for soil health and sustainable development through supplementing with soil organic matter, increasing the water holding capacity, releasing nutrients and enhancing soil aggregation, and promoting soil biological activity [7]. The selection of an appropriate organic mulching material is strongly affected by the local climate, cost-effectiveness, and feasibility for the crop [8].

Mushrooms have drawn a lot of interest owing to their nutritional and medicinal value, and they have been widely cultivated. Nowadays, a total of 34 billion kg of mushrooms are produced annually throughout the world [9]. As the largest edible mushroom producer and exporter in the world, China's main production areas are Henan, Fujian, Shandong, and Hebei province. Pingquan County, which belongs to Hebei Province, is the main pholiota nameko production base in northern China. After the mushroom fruiting bodies are harvested, a huge amount of solid fermented waste is produced. Because a high level of organic matter remains present in the spent mushroom substrate (SMS), it should be properly disposed of to avoid environmental pollution problems. Previously, the major applications of SMS were animal fodder, composting material, and bioenergy feedstock [10]. However, most SMS is still stacked on farmland or incinerated at will. SMS has become the biggest challenge for mushroom farms in terms of disposal management, although studies have confirmed that SMS is a good biofertilizer or soil improver for crop production thanks to its high amounts of macro- and micronutrients, high cation exchange capacity, near-neutral $\mathrm{pH}$, high porosity, and high water-holding capacity [11]. SMS, with its biodegradability, availability, and sustainability, could be a promising alternative to traditional plastic mulch in the context of global plastic-reduction behavior.

At present, there is little information about the use of SMS as a mulching material and the assessment of the effects of mulching thickness on the soil-plant system. The efficacy of SMS mulch needs to be verified and evaluated. Keeping the above facts in mind, this study focused on four aspects regarding the short-term effects of mulching thickness: (1) the physico-chemical and biological properties of the soil, (2) weed suppression, (3) leaf nutrients, and (4) nut characteristics. The purpose of this study is to find a suitable SMS mulching measure to improve the soil health and nut quality. The results of this study could be used as references for SMS utilization and environmentally friendly mulching practices. 


\section{Materials and Methods}

\subsection{Description of Experimental Sites and Plant Materials}

The field experiment was conducted from October 2018 to December 2019 in the North experiment station of Beijing Forestry University $\left(118^{\circ} 40^{\prime} 46^{\prime \prime}\right.$ E, $\left.41^{\circ} 13^{\prime} 18^{\prime \prime} \mathrm{N}\right)$, Sudayingzi village, Pingquan County, Hebei Province, China. It is located in a temperate monsoon climate zone. The annual average temperature in the past ten years has been about $7.5^{\circ} \mathrm{C}$. The average annual rainfall in the past ten years has been about $540 \mathrm{~mm}$, and this has been mainly concentrated in summer. The average number of annual sunshine hours in the past ten years has been about $2500 \mathrm{~h}$ with a frost-free period of 120-130 d. The local agrometeorological data for 2019 are depicted in Table 1. The soil texture of the experiment plot is sandy loam soil. The soil total nitrogen, available phosphorus, available potassium, alkali hydrolyzed nitrogen, and organic matter contents are $0.83 \pm 0.06,15.67 \pm 2.41$, $105.56 \pm 10.63,32.13 \pm 2.45$, and $13.43 \pm 1.17$, respectively; the soil $\mathrm{pH}$ value is 6.5 . The hazelnut plantation is mainly planted with the hybrid hazelnut Corylus heterophylla $\times$ Corylus avellana ' $82-11^{\prime}$. This cultivar was planted in 2013 with plant and row spacings of 2 and $3 \mathrm{~m}$, respectively.

Table 1. The local agrometeorological data for 2019.

\begin{tabular}{ccccc}
\hline Month & $\begin{array}{c}\text { Average } \\
\text { Temperature } \\
\left({ }^{\circ} \mathbf{C}\right)\end{array}$ & $\begin{array}{c}\text { Average } \\
\text { Relative } \\
\text { Humidity (\%) }\end{array}$ & $\begin{array}{c}\text { Average } \\
\text { Rainfall (mm) }\end{array}$ & $\begin{array}{c}\text { Average } \\
\text { Sunshine Hours } \\
\text { (h) }\end{array}$ \\
\hline Jan. & -10 & 50.6 & 2.2 & 195.1 \\
Feb. & -5.6 & 44.6 & 3.8 & 195.0 \\
Mar. & 2.1 & 40.6 & 9.1 & 229.2 \\
Apr. & 10.4 & 41.2 & 20.3 & 225.2 \\
May. & 16.8 & 48.0 & 51.6 & 240.4 \\
June. & 20.7 & 65.2 & 97.8 & 188.5 \\
July. & 23.5 & 75.4 & 152.7 & 182.1 \\
Aug. & 21.8 & 74.6 & 121.2 & 195.7 \\
Sept. & 16.7 & 70.2 & 46.6 & 206.9 \\
Oct. & 8.4 & 64.0 & 20.3 & 209.0 \\
Nov. & -0.5 & 57.1 & 7.5 & 184.5 \\
Dec. & -7.8 & 53.9 & 2.5 & 178.9 \\
\hline
\end{tabular}

\subsection{Experimental Design and Treatments}

The mulching experiment was conducted in October 2018 with a total of four treatments. The treatments were non-mulching control (CK), a mulch thickness of $5 \mathrm{~cm}$ (MT1), a mulch thickness of $10 \mathrm{~cm}$ (MT2), and a mulch thickness of $15 \mathrm{~cm}$ (MT3). This experiment had a randomized complete block design, where each mulching treatment was replicated three times and the plot area of each treatment was $40 \mathrm{~m}^{2}(8 \mathrm{~m} \times 5 \mathrm{~m})$. A diagram of the experimental design is shown in Figure 1. The mulching material used was residue from the local production of Pholiota nameko. The main component of the residue was sawdust from the branches of Robinia pseudoacacia that had not been completely decomposed. The total nitrogen content, available potassium content, organic matter content, and $\mathrm{pH}$ value of the SMS were $30.74 \pm 2.36,232.78 \pm 20.64,421.69 \pm 30.82$, and 5.4, respectively. 


\begin{tabular}{|c|c|c|c|c|}
\hline \multirow{7}{*}{$\begin{array}{c}\text { protective } \\
\text { rows }\end{array}$} & \multicolumn{3}{|c|}{ protective rows } & \multirow{7}{*}{$\begin{array}{c}\text { protective } \\
\text { rows }\end{array}$} \\
\hline & Block I & Block II & Block III & \\
\hline & MT2 & MT2 & CK & \\
\hline & $\mathrm{CK}$ & MT3 & MT1 & \\
\hline & MT1 & CK & MT2 & \\
\hline & MT3 & MT1 & MT3 & \\
\hline & & tective $\mathrm{rc}$ & & \\
\hline
\end{tabular}

Figure 1. Schematic diagram of the randomized block experiment design. CK, control; MT, mulch thickness.

\subsection{Sampling}

The soil located 0-20 $\mathrm{cm}$ under the mushroom mulch was sampled with a stainlesssteel cylindrical drill at 15-day intervals from May to December in 2019. Five soil sampling points were selected in each experimental plot by the S-shape sampling method. In each plot, one soil sample was composed of five individual samples, and about $1 \mathrm{~kg}$ of soil was reserved by the coning and quartering method. The samples from different treatments were dried in a ventilation place and then sieved by stainless-steel sieves with pore sizes of 1.00 and $0.25 \mathrm{~mm}$. The $\mathrm{pH}$ value, available nutrient content, and enzyme activity of the soil samples $(<1.00 \mathrm{~mm})$ were used. The soil samples $(<0.25 \mathrm{~mm})$ were used to determine the total nutrient content and organic matter content of soil.

About 30 mature leaves in the upper or middle parts of the branches of the tested trees were also collected from each experimental plot from May to October in 2019. The fresh leaves were dried at a low temperature $\left(35^{\circ} \mathrm{C}\right)$ to ensure their weights were constant. Then, the dried leaves were crushed with a pulverizer. Finally, the classified powder was obtained through a 100-mesh steel sieve and prepared for nitrogen, phosphorus, and potassium analyses.

\subsection{Measurements}

\subsubsection{Soil Moisture and Temperature}

A remote real-time monitoring instrument (Patent No. CN202648697U) was installed in each plot to measure soil moisture content (accuracy: $\pm 3 \%$ ) and soil temperature (accuracy: $\pm 0.5^{\circ} \mathrm{C}$ ). Each instrument was connected with three moisture sensor probes and three temperature sensor probes. The moisture sensor probes were set at 15, 30, and $45 \mathrm{~cm}$ underground, and the temperature sensor probes were set at the surface level of the ground, $10 \mathrm{~cm}$ underground, and $20 \mathrm{~cm}$ underground. This instrument automatically records data every $10 \mathrm{~min}$. The recorded data can be viewed online through the data transmission module.

\subsubsection{Physico-Chemical and Biological Properties of Soil}

Undisturbed topsoil cores were collected with a ring knife (diameter, $50.46 \mathrm{~mm}$; length, $50 \mathrm{~mm}$ ) and dried to a constant weight in an oven at $105^{\circ} \mathrm{C}$ to measure the bulk density and total porosity [12]. Soil organic matter (SOM) was determined with the potassium dichromate and sulfuric acid method [13]. Alkaline hydrolysable-nitrogen (AH-N) was measured by the alkali solution diffusion method [14]. Available phosphorus (AP) was extracted with $0.5 \mathrm{~mol} / \mathrm{L} \mathrm{NaHCO}_{3}(\mathrm{pH} 8.5)$ and determined by molybdenum-antimony anti-colorimetry with an ultraviolet spectrophotometer (Lambda750, PerkinElmer Inc., Waltham, MA, USA). Available potassium (AK) was determined in ammonium acetate 
extracts by flame photometry with an atomic absorption spectrophotometer (AA-240, Varian Inc., Palo Alto, CA, USA) [15].

Urease activity was measured using the phenol sodium hypochlorite colorimetric method and expressed in mg of $\mathrm{NH}_{4}{ }^{+}-\mathrm{N}$ in $1 \mathrm{~g}$ of dry soil after $24 \mathrm{~h}$. Invertase activity was determined by the 3,5-dinitrosalicylic acid colorimetric method and shown as mg glucose in $1 \mathrm{~g}$ dry soil after $24 \mathrm{~h}$. Catalase activity was determined using the $\mathrm{KMnO}_{4}$ titration method and shown as the consumption volume $(\mathrm{mL})$ of $0.1 \mathrm{~mol} \cdot \mathrm{L}^{-1} \mathrm{KMnO}_{4}$ in $1 \mathrm{~g}$ of dry soil after $20 \mathrm{~min}$ [16].

\subsubsection{Weed Investigation}

In order to determine the effect of mulching measures on weed growth, three small plots of $0.6 \mathrm{~m} \times 0.6 \mathrm{~m}$ were randomly selected from each plot to investigate weed suppression in June, August, and October of 2019. Using statistics on the number of weed species and the fresh weight of the weeds, the controlling effect of mulching measures on weeds was reflected. The weed control efficiency (WCE) can be calculated using the following formula $[17,18]$ :

$$
\mathrm{WCE}=(\mathrm{DMC}-\mathrm{DMT}) / \mathrm{DMC} \times 100
$$

where DMC is the dry matter of weeds subjected to CK treatment, and DMT is the dry matter of weeds in a particular treatment.

\subsubsection{Leaf Nutrients and Chlorophyll Content}

The leaf $\mathrm{N}$ concentration was determined using the micro-Kjeldahl method with a nitrogen determinator (Kjeltec ${ }^{\mathrm{TM}}$ 8000, FOSS Group, Hiller, Denmark) [19]. The total leaf $\mathrm{P}$ concentrations were measured with a molybdate/stannous chloride method with an ultraviolet spectrophotometer (Lambda750, PerkinElmer Inc., Waltham, MA, USA) [20]. The leaf $\mathrm{K}$ concentrations were determined by atomic absorption spectrometry with an atomic absorption spectrophotometer (AA-240, Varian Inc., Palo Alto, CA, USA) [21]. The chlorophyll content in leaves was estimated using a hand-held chlorophyll meter (SPAD-502, Konica Minolta Optics, Osaka, Japan) [22].

\subsubsection{Nut Traits}

Hazelnuts exposed to different mulch treatments were harvested in October 2019, and 100 nuts were randomly selected form each treatment to determine the nut traits. The experimental procedure included the following steps: (1) three linear dimensions of hazelnuts-length $(L)$, width $(W)$, and thickness $(T)$ - were measured in mm with an electronic digital caliper [23]. (2) The nuts were dried in an oven at $40^{\circ} \mathrm{C}$ for 5 days to reach a constant weight, and then the dry nuts' mass $(N M)$ was weighed with a laboratory balance that was accurate to $0.01 \mathrm{~g}$ (Practum5101-1CN, Sartorius Group, Goettingen, Germany). (3) The dry kernels were taken out of the nut shells using a hammer, and the mass of the dry kernels was weighed (KM). (4) The kernels were ground via ball milling (Retsch MM400, Verder Group, Haan, Germany) with liquid nitrogen to produce powder samples. (5) The powder samples were used to determine the crude protein, soluble sugar, and crude fat contents (CPC, SSC, and CFC).

The soluble sugar concentration was determined by colorimetry with anthrone reagent in an ultraviolet spectrophotometer at $620 \mathrm{~nm}$. A standard glucose curve was plotted, and the soluble sugar and glucose concentrations were interpolated from it. The crude protein content of the kernel samples was determined with the Kjeldahl method. The protein content was calculated using a factor of 6.25 for the $\mathrm{N}$ content [24]. The total fat content was obtained using the Soxhlet extraction method [24]. The crude fat content was calculated by dividing the dried extracted oil mass by the dried powder sample mass. 
To describe the main morphological characteristics of nuts, some physical parameters were calculated according to Equations [23]:

$$
V=\frac{\pi L W T}{6}, D=(L W T)^{\frac{1}{3}}, \varnothing=\frac{D}{L}, P K=\frac{K M}{N M} \times 100, N S I=\frac{W+T}{2 L}
$$

where $V$ is the volume of nuts $\left(\mathrm{cm}^{3}\right), \pi$ is the circumference ratio $(\approx 3.14), L$ is the length of the nut (mm), $W$ is the width of the nut $(\mathrm{mm}), T$ is the thickness of the nut $(\mathrm{mm}), D$ is the geometric mean diameter of the nut $(\mathrm{mm}), \varnothing$ is the sphericity of the nut, $P K$ is the kernel percentage, KM is the kernel mass $(\mathrm{g}), N M$ is the nut mass $(\mathrm{g})$, and NSI is the nut shape index.

\subsection{Statistical Analysis}

Each determination was performed in triplicate, and the data are reported as means \pm standard deviations. The data variables from this study were subjected to an analysis of variance using SPSS statistical software package version 18.0 (SPSS Inc., Chicago, IL, USA), which was also used to carry out Duncan's multiple comparisons test to analyze the differences in various parameters in different experimental treatments. For all statistical analyses, $p \leq 0.05$ was considered significant and $p \leq 0.01$ was deemed to be very significant. All figures in this manuscript were drawn with Excel 2010.

\section{Results}

\subsection{Effect of the Mulching Thickness on Soil Physico-Chemical and Biological Properties 3.1.1. Soil Temperature}

There were significant differences in the monthly variation of the soil temperature at different soil depths for each treatment (Table 2). During the field experiment period, for each treatment, the soil temperature at different soil depths showed a trend of first rising and then falling, reaching a peak in August and a valley in December. The average topsoil temperature of CK was $0.77,1.32$, and $1.81^{\circ} \mathrm{C}$ higher than that of MT1, MT2, and MT3 in the growth period (from May to October), respectively. However, in the dormancy period (from November to December), the average topsoil temperature of $\mathrm{CK}$ was $0.32,0.75$, and $1.17^{\circ} \mathrm{C}$ lower than that of MT1, MT2, and MT3, respectively. There were significant differences in the topsoil temperature between the MT2, MT3, and CK treatments throughout the study period.

The average soil temperature during the mulching treatments was significantly lower than that of CK in the growth period at a depth of $10 \mathrm{~cm}$ with magnitudes of $16.64 \pm 0.14$, $16.28 \pm 0.16$, and $15.86 \pm 0.13{ }^{\circ} \mathrm{C}$ for MT1, MT2, and MT3, respectively. During the dormancy period, the average soil temperature of CK was $0.42,1.02$, and $1.56{ }^{\circ} \mathrm{C}$ lower than that of MT1, MT2, and MT3, respectively. There were significant differences in the soil temperature of at a depth of $10 \mathrm{~cm}$ between the mulching and non-mulching treatments.

Compared with CK, at a depth of $20 \mathrm{~cm}$, MT1, MT2, and MT3 decreased the soil temperature by an average of $0.30,0.51$, and $0.83{ }^{\circ} \mathrm{C}$ in the growth period and increased the soil temperature by $0.26,0.71$, and $1.05^{\circ} \mathrm{C}$ in the dormancy period. There were significant differences in the soil temperature between the MT3 and CK treatments during the study period at a depth of $20 \mathrm{~cm}$.

\subsubsection{Soil Water}

In this study, the soil water content was investigated at depths of 15,30 , and $45 \mathrm{~cm}$ because the fine-roots of $C$. heterophylla $\times C$. avellana are mainly distributed in the depth range of $0-50 \mathrm{~cm}$ [25]. The soil water content was significantly affected by the mulching practices, and it varied spatially and temporally (Table 3 ). 
Table 2. Monthly average soil temperature $\left({ }^{\circ} \mathrm{C}\right)$ at different soil depths during the field experiment period for the mulch treatments.

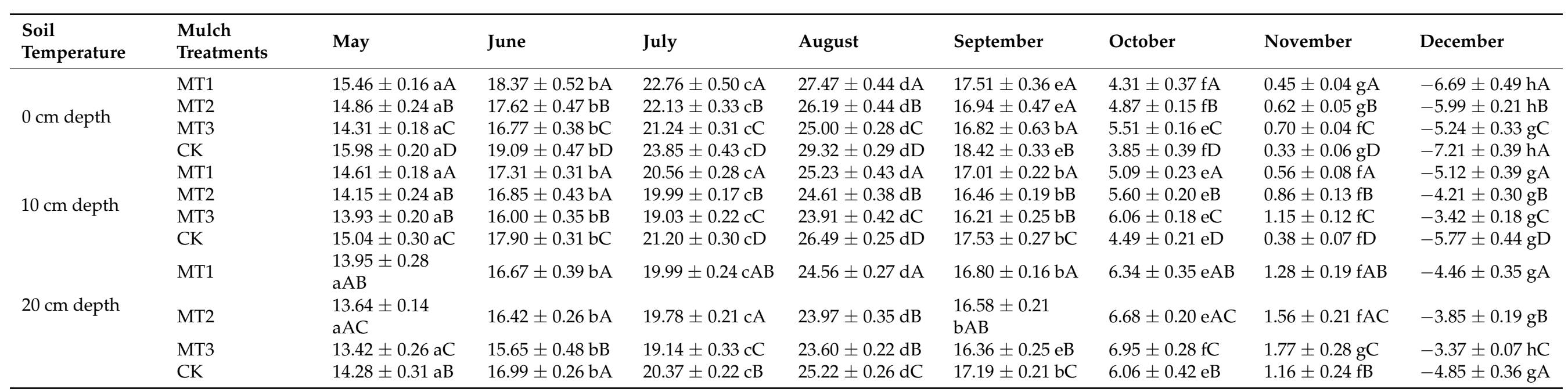

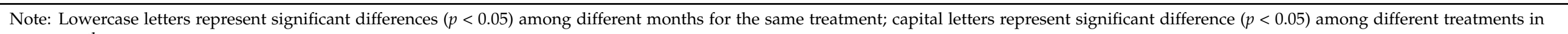
same month.

Table 3. Monthly average soil water content (\%) at different soil depths during the field experiment period for the mulch treatments.

\begin{tabular}{|c|c|c|c|c|c|c|c|c|c|}
\hline Soil Water & $\begin{array}{l}\text { Mulch } \\
\text { Treatments }\end{array}$ & May & June & July & August & September & October & November & December \\
\hline \multirow{5}{*}{$15 \mathrm{~cm}$ depth } & MT1 & $19.64 \pm 1.06 \mathrm{aA}$ & $22.47 \pm 1.23 \mathrm{bcA}$ & $23.35 \pm 1.43 \mathrm{bA}$ & $20.11 \pm 1.02 \mathrm{adA}$ & $21.11 \pm 1.05 \operatorname{acd} \mathrm{A}$ & $21.36 \pm 1.02 \mathrm{cdA}$ & $19.78 \pm 0.97 \mathrm{adA}$ & $9.25 \pm 0.46 \mathrm{eA}$ \\
\hline & MT2 & $20.01 \pm 1.09 \mathrm{aA}$ & $25.54 \pm 1.53 \mathrm{bB}$ & $26.31 \pm 0.89 \mathrm{bB}$ & $22.32 \pm 0.96 \mathrm{cdB}$ & $22.69 \pm 1.10 \mathrm{cA}$ & $22.27 \pm 1.00 \mathrm{cdA}$ & $20.84 \pm 0.66$ adAB & $10.34 \pm 0.38 \mathrm{eB}$ \\
\hline & MT3 & $20.90 \pm 3.37 \mathrm{aA}$ & $21.73 \pm 1.16 \mathrm{aA}$ & $22.38 \pm 1.10 \mathrm{aAC}$ & $20.89 \pm 1.27 \mathrm{aAB}$ & $21.05 \pm 1.31 \mathrm{aA}$ & $21.63 \pm 1.17 \mathrm{aA}$ & $21.46 \pm 0.47 \mathrm{aB}$ & $13.86 \pm 0.47 \mathrm{bC}$ \\
\hline & CK & $15.87 \pm 1.25 \mathrm{aB}$ & $20.32 \pm 1.77 \mathrm{bA}$ & $20.51 \pm 1.37 \mathrm{bC}$ & $19.64 \pm 1.32 \mathrm{bcA}$ & $20.84 \pm 1.11 \mathrm{bA}$ & $21.01 \pm 0.74 \mathrm{bA}$ & $18.33 \pm 0.99 c C$ & $8.78 \pm 0.46 \mathrm{dA}$ \\
\hline & MT1 & $20.90 \pm 0.50 \mathrm{aAB}$ & $24.54 \pm 1.42 \mathrm{bAB}$ & $24.71 \pm 1.01 \mathrm{bAB}$ & $21.87 \pm 1.24 \mathrm{acAB}$ & $22.35 \pm 1.07 \mathrm{acAB}$ & $23.27 \pm 0.76$ bc $A B$ & $21.24 \pm 0.86 \mathrm{aA}$ & $12.26 \pm 0.33 \mathrm{dA}$ \\
\hline \multirow{3}{*}{$30 \mathrm{~cm}$ depth } & MT2 & $22.66 \pm 1.28 \mathrm{abB}$ & $26.05 \pm 1.40 \mathrm{cA}$ & $25.58 \pm 1.06 \mathrm{cA}$ & $23.34 \pm 0.91 \mathrm{aA}$ & $23.56 \pm 0.90 \mathrm{aA}$ & $23.86 \pm 1.04 \mathrm{aA}$ & $21.59 \pm 0.67 \mathrm{bA}$ & $14.52 \pm 0.35 \mathrm{~dB}$ \\
\hline & MT3 & $22.13 \pm 1.88 \mathrm{abB}$ & $22.15 \pm 1.18 \mathrm{abC}$ & $23.51 \pm 0.87 \mathrm{aBC}$ & $21.54 \pm 0.64 \mathrm{bB}$ & $21.75 \pm 1.04 \mathrm{bB}$ & $22.38 \pm 0.97 \mathrm{abB}$ & $21.77 \pm 0.30 \mathrm{bA}$ & $18.44 \pm 0.38 c C$ \\
\hline & CK & $18.99 \pm 1.09 \mathrm{aA}$ & $22.76 \pm 0.83 \mathrm{bBC}$ & $22.82 \pm 0.90 \mathrm{bC}$ & $21.14 \pm 1.19 \mathrm{cdB}$ & $22.18 \pm 0.79 \mathrm{bcAB}$ & $22.04 \pm 0.82 \mathrm{bcdB}$ & $20.83 \pm 0.63 \mathrm{dA}$ & $10.28 \pm 0.27 \mathrm{eD}$ \\
\hline \multirow{4}{*}{$45 \mathrm{~cm}$ depth } & MT1 & $24.23 \pm 1.95 \mathrm{abA}$ & $25.45 \pm 1.64 \mathrm{aAB}$ & $25.81 \pm 0.93 \mathrm{aA}$ & $23.66 \pm 0.52 \mathrm{bA}$ & $23.67 \pm 0.49 \mathrm{bA}$ & $23.52 \pm 0.61 \mathrm{bAB}$ & $21.76 \pm 0.45 \mathrm{cAB}$ & $19.46 \pm 0.41 \mathrm{dA}$ \\
\hline & MT2 & $24.77 \pm 0.68 \mathrm{aA}$ & $26.86 \pm 0.72 \mathrm{bA}$ & $27.35 \pm 0.50 \mathrm{bB}$ & $23.81 \pm 0.72 \mathrm{cA}$ & $23.72 \pm 0.66 \mathrm{cA}$ & $23.79 \pm 0.84 \mathrm{cA}$ & $22.06 \pm 0.39 \mathrm{dA}$ & $20.87 \pm 0.40 \mathrm{eB}$ \\
\hline & MT3 & $24.90 \pm 1.81 \mathrm{aA}$ & $24.14 \pm 1.35 \mathrm{abB}$ & $24.51 \pm 1.01 \mathrm{abAC}$ & $23.08 \pm 0.55 \mathrm{bcAB}$ & $23.78 \pm 0.35 \mathrm{abcA}$ & $23.25 \pm 0.62 \mathrm{bcAB}$ & $22.36 \pm 0.35 \mathrm{cdA}$ & $21.19 \pm 0.33 \mathrm{~dB}$ \\
\hline & CK & $21.62 \pm 1.76 \mathrm{aB}$ & $23.69 \pm 1.22 \mathrm{bB}$ & $23.57 \pm 1.06 \mathrm{bC}$ & $22.24 \pm 0.67 \mathrm{abB}$ & $22.57 \pm 0.93 \mathrm{abB}$ & $22.36 \pm 0.85 \mathrm{abB}$ & $21.25 \pm 0.47 \mathrm{aB}$ & $17.31 \pm 0.50 \mathrm{cC}$ \\
\hline
\end{tabular}

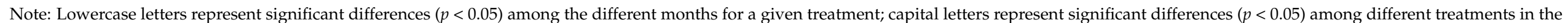
same month. 
The average soil water content of CK showed a monthly fluctuation and was strongly affected by rainfall and evaporation. The average soil water content of the mulch treatments showed a dynamic rising-stable-declining trend during the field experiment period. The soil water content of MT1, MT2, and MT3 was $8.13 \%, 17.23 \%$, and $12.81 \%$ higher than that of CK, respectively, at a depth of $15 \mathrm{~cm}$. At a depth of $30 \mathrm{~cm}$, the soil water content of MT1, MT2 and MT3 was 6.27\%, 12.48\%, and 7.84\% higher than that of CK, respectively. The soil water content of CK was $7.41 \%, 10.66 \%$, and $7.20 \%$ lower than that of MT1, MT2, and MT3, respectively, at a soil depth of $45 \mathrm{~cm}$. In this study, the average soil water content increased as the soil depth increased. The soil water content first increased and then decreased as the mulching thickness increased (from 0 to $15 \mathrm{~cm}$ ), and the $10 \mathrm{~cm}$ mulching thickness treatment had a better water holding capacity. The SMS mulching not only had a positive effect by improving the soil water content, but it also effectively alleviated the soil moisture variation.

\subsubsection{Soil Bulk Density and Porosity}

The monthly dynamics of the soil bulk density and porosity under the different mulching thickness treatments are shown in Figure 2.
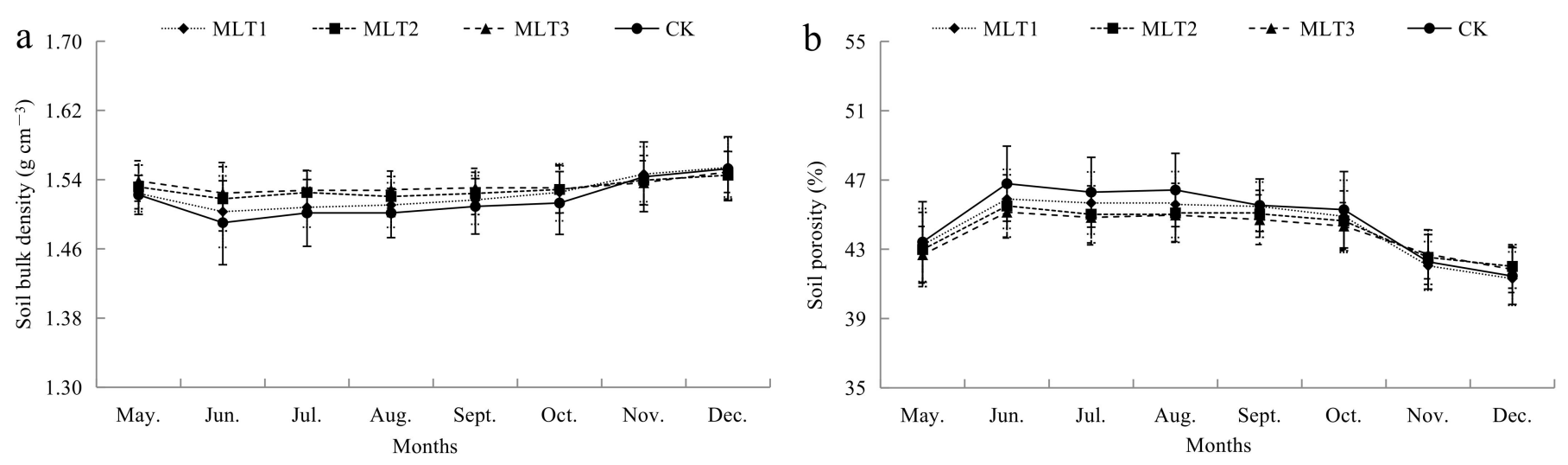

Figure 2. Variation in the soil physical properties among different treatment groups during the field experiment period: (a) soil bulk density and (b) soil porosity.

Figure 2a depicts the dynamic variation in the soil bulk density during these mulch treatments throughout the field experiment period. The lowest and highest bulk densities of these treatments appeared in June and December, respectively. All treatments had similar dynamic trends, that is, the density first decreased (from May to June), then stabilized (from July to October), and finally increased (in November and December). In a field experiment period of one year, the bulk density tended to increase as the mulching thickness increased. The MT3 treatment had the highest average bulk density $\left(1.533 \mathrm{~g} \mathrm{~cm}^{-3}\right)$, followed by MT2 $\left(1.529 \mathrm{~g} \mathrm{~cm}^{-3}\right)$, MT1 $\left(1.524 \mathrm{~g} \mathrm{~cm}^{-3}\right)$, and CK $\left(1.517 \mathrm{~g} \mathrm{~cm}^{-3}\right)$.

In this study, different mulch treatments reduced the soil porosity. The general dynamic variation in the soil porosity was in contrast to that of the bulk density, showing a trend of first rising and then decreasing (Figure $2 b$ ). There were no significant differences in soil porosity among these treatments throughout the field experiment period. The highest and lowest total porosities recorded for these treatment groups all appeared in June and December, respectively. The MT3 treatment was associated with the lowest average total porosity (43.9\%), followed by MT2 (44.1 \%), MT1 (44.3\%), and CK (44.7\%).

\subsubsection{Soil Nutrients}

Figure 3a presents the monthly dynamics of the SOM content under different mulching thicknesses. The change trend for the SOM content in MT1, MT2, and MT3 was an initial increase and then a decrease. In the CK treatment, the trend was a continuous decrease at first, followed by a stable period. There were no significant differences in the SOM 
content among MT1, MT2, and MT3. However, the SOM concentration of the mulched plots was significantly higher than that of the plots, with no mulch from July to October. With an increase in the mulching thickness, the SOM concentration tended to increase. During the field experiment period, MT3 had the highest average SOM concentration $\left(16.10 \pm 1.29 \mathrm{~g} \mathrm{~kg}^{-1}\right)$, slightly higher than that of MT2 $\left(15.89 \pm 1.33 \mathrm{~g} \mathrm{~kg}^{-1}\right)$ and MT1 $\left(15.35 \pm 1.66 \mathrm{~g} \mathrm{~kg}^{-1}\right)$, while the lowest average SOM content, which was only $13.65 \pm 1.85 \mathrm{~g} \mathrm{~kg}^{-1}$, occurred in CK.
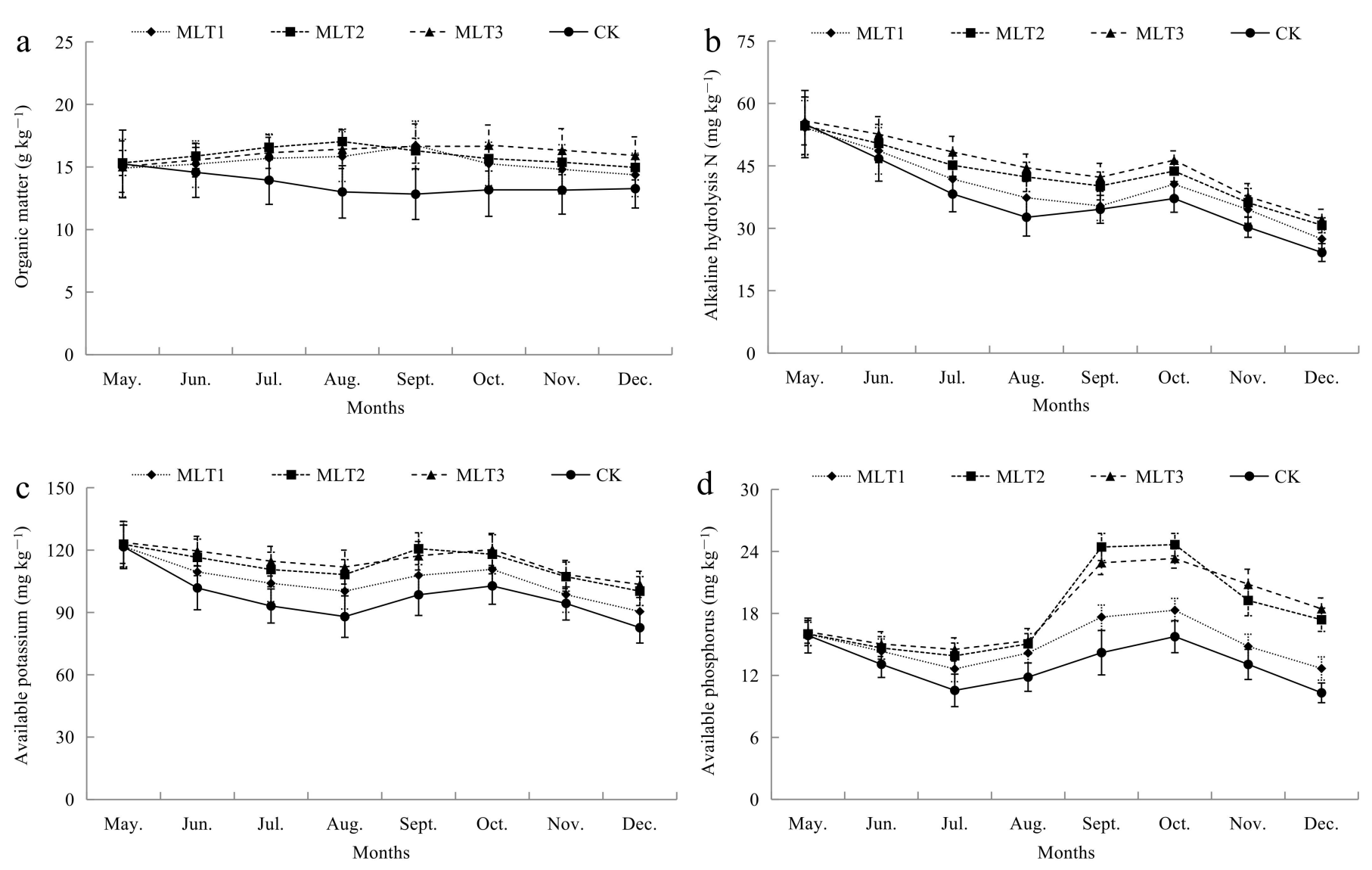

Figure 3. Variation in soil nutrient contents among different treatments during the field experiment period: (a) organic matter; (b) alkaline hydrolyzable nitrogen; (c) available potassium; (d) available phosphorus.

Figure $3 \mathrm{~b}$ depicts the monthly dynamics of the AH-N content with different mulch treatments. The dynamic changes in the AH-N content in these treatments were similar; that is, there was an initial rapid decrease, followed by a slight increase and, finally, an obvious decrease. The highest AH-N content of each treatment appeared in May, and the lowest value appeared in December. There were significant differences in the AH-N content not only in different months, but also for different treatments. The average AH-N content in soil exposed to the MT3 treatment was $20.39 \%, 12.46 \%$, and $4.77 \%$ higher than that for CK, MT1, and MT2, respectively.

The monthly dynamics of the AK content in soil exposed to the mulch treatments are shown in Figure 3c. The change trend for the AK content in soil exposed to these treatments was similar among groups, with all of them showing a decline-rise-decline fluctuation during the study period. The AK contents of MT2 and MT3 were significantly higher than that of CK. MT3 had the highest average AK concentration $\left(114.89 \pm 4.97 \mathrm{mg} \mathrm{kg}^{-1}\right)$, followed by MT2 $\left(113.04 \pm 4.77 \mathrm{mg} \mathrm{kg}^{-1}\right)$, MT1 $\left(105.37 \pm 4.58 \mathrm{mg} \mathrm{kg}^{-1}\right)$, and CK $\left(97.85 \pm 6.26 \mathrm{mg} \mathrm{kg}^{-1}\right)$.

Figure $3 \mathrm{~d}$ illustrates the monthly dynamics of the AP content in soil exposed to different mulch treatments. The dynamic change trend in the AP content was similar to that of the AH-N and AK contents. There were significant differences in the AP content 
among these treatments. The AP contents of MT2 and MT3 were much higher than those of CK and MT1 from September to December. MT3 had the highest average AP concentration $\left(18.32 \pm 0.62 \mathrm{mg} \mathrm{kg}^{-1}\right)$, which was $40.11 \%, 21.59 \%$, and $0.85 \%$ higher than that of CK, MT1, and MT2, respectively.

\subsubsection{Soil Enzymatic Activities}

Soil enzymes are some of the most active components in various biochemical processes and nutrient cycles. They play an important role in the degradation of SOM and nutrient mineralization [26,27]. The dynamics of three soil enzymatic activities under different mulch treatments are shown in Figure 4.
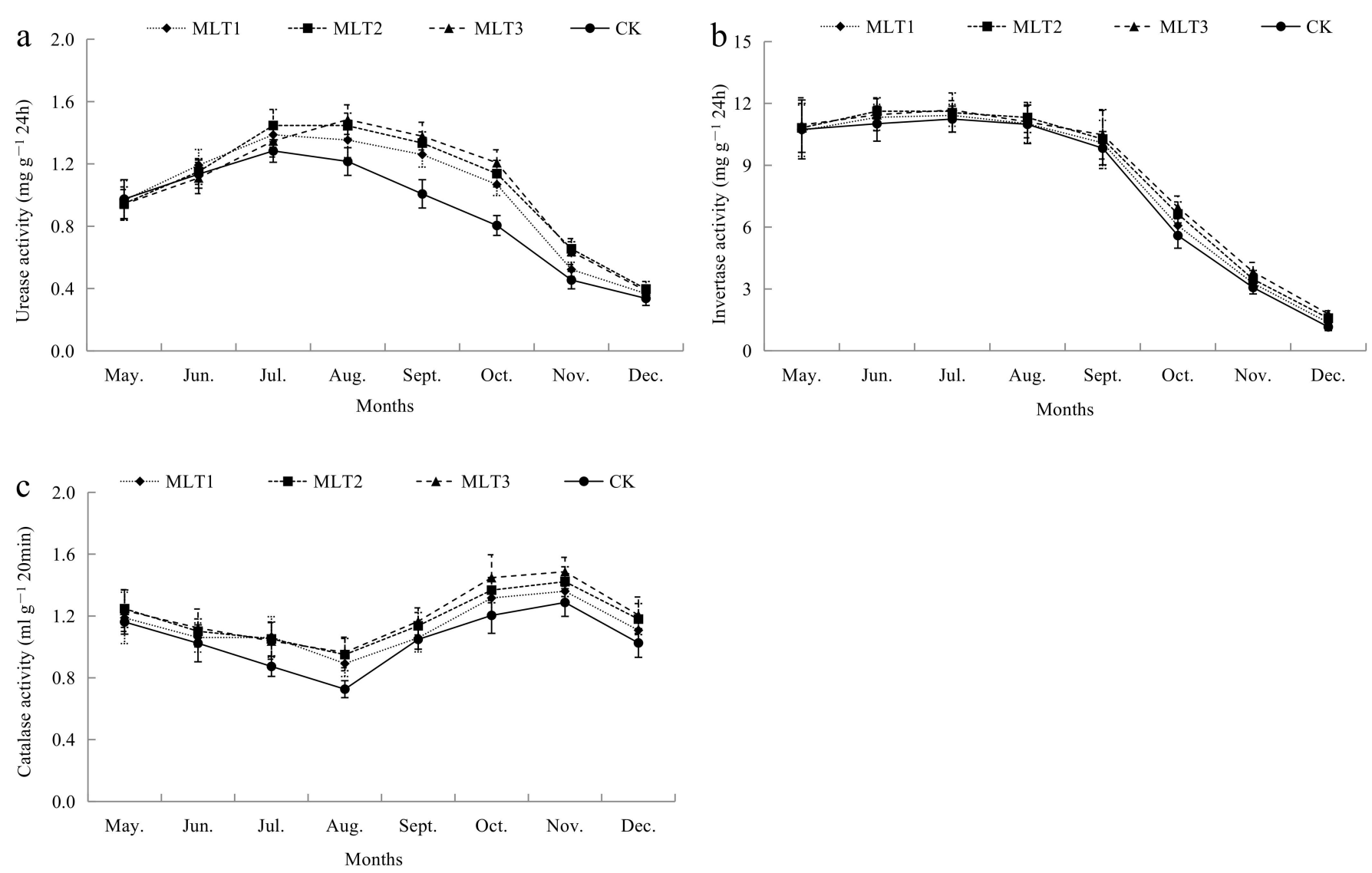

Figure 4. Variation in soil enzymatic activities among different treatment groups during the field experiment period:

(a) urease activity; (b) invertase activity; (c) catalase activity.

The urease activity varied significantly across the sampling period and with different mulching thickness gradients (Figure 4a). In MT1, MT2, and MT3, the urease activity went through a rising period and was maintained at a high level before sharply decreasing over time. However, the urease activity decreased in CK after the rising period. The urease activity was higher in summer and lower in winter. The average urease activity of MT1, MT2, and MT3 increased by $12.56 \%, 18.04 \%$, and $17.74 \%$, respectively, compared with that of CK.

The invertase activity dynamics of the four treatments all showed a similar trend: a slight increase at first and then a rapid decrease (Figure 4b). The invertase activity of these four treatments was higher in summer, while lower invertase activity occurred in winter. MT3 had the highest average invertase activity $\left(8.53 \pm 0.46 \mathrm{mg} \mathrm{g}^{-1} .24 \mathrm{~h}^{-1}\right)$, followed by MT2 $\left(8.41 \pm 0.37 \mathrm{mg} \mathrm{g}^{-1} .24 \mathrm{~h}^{-1}\right)$, MT1 $\left(8.16 \pm 0.36 \mathrm{mg} \mathrm{g}^{-1} .24 \mathrm{~h}^{-1}\right)$, and CK $\left(7.95 \pm 0.47 \mathrm{mg} \mathrm{g}^{-1} \cdot 24 \mathrm{~h}^{-1}\right)$. 
Figure 4c shows the monthly dynamics of catalase activity in soil exposed to these mulch treatments. The catalase activity showed a similar trend in these treatment groups with a decline-rise-decline fluctuation during the sampling period. The catalase activity differed significantly among sample sets from different months and with different mulching thickness gradients. The catalase activity of each treatment group was higher in autumn and lower in late summer. The average catalase activity of MT1, MT2, and MT3 was 8.35\%, $13.24 \%$, and $15.76 \%$ higher, respectively, than that of CK.

\subsection{Effect of Mulching Thickness on Weed Suppression}

The investigation of weeds was carried out in June, August, and October. In total, 18 weed species belonging to nine families were identified from these treatments (Table 4). Weed biomass and control efficiency are presented in Table 4.

In June, there were 8, 5, 3, and 14 weed species in MT1, MT2, MT3, and CK, respectively. The dominant weed species in CK were Cephalanoplos segetum (Willd.) MB., Conyza canadensis (L.) Cronq., Equisetum hyemale L., Ixeris sonchifolia (Bunge) Hance, and Taraxacum mongolicum Hand.-Mazz. Chenopodium album L., Eleusine indica (L.) Gaertn., and Ixeris sonchifolia (Bunge) Hance were found in all treatment groups. In August, the number of weed species decreased in MT1 (7 species) and CK (10 species). The major weeds found in CK changed to Amaranthus retroflexus L., Chenopodium album L., Eleusine indica (L.) Gaertn., and Equisetum hyemale L.. Amaranthus retroflexus L., Chenopodium album L. and Ixeris sonchifolia (Bunge) Hance appeared in all treatments. In October, the number of weed species in MT1 (4 species), MT2 (4 species), MT3 (1 species), and CK (7 species) reduced obviously. Ixeris sonchifolia (Bunge) Hance, Equisetum hyemale L., and Xanthium sibiricum Patrin ex Widder became the dominant weed species. Ixeris sonchifolia (Bunge) Hance was found in all plots.

The highest weed dry biomass content was recorded in June for CK (1563.86 \pm $\left.116.33 \mathrm{~g} \mathrm{~m}^{-2}\right)$, whereas the lowest weed biomass was recorded in October (318.46 \pm $20.13 \mathrm{~g} \mathrm{~m}^{-2}$ ). In early summer (June), the weed biomass of mulched plots was much less than that of plots with no mulch, and the weed control efficiency ranged from $79.01 \%$ to 97.90\%. In August, the weed biomass of MT1, MT2, and MT3 increased by $37.84 \%, 250.46 \%$, and $687.52 \%$, respectively, compared with that in June, while the weed control efficiencies decreased to $48.25 \%, 55.66 \%$, and $70.43 \%$, respectively. The weed biomass of the mulched plots decreased significantly in October, and the weed control efficiency improved greatly, ranging from $80.42 \%$ to $96.63 \%$. The highest level of weed suppression, $70.43-97.90 \%$, was obtained with MT3, followed by MT2 (55.66-92.93\%), and the lowest level was found in the MT1 plots (48.25-80.42\%).

With an increase of mulching thickness, the number of weed species decreased obviously and the weed control efficiency increased. SMS mulching was better able to control the growth of Conyza canadensis (L.) Cronq., Cephalanoplos segetum (Willd.) MB., Humulus scandens (Lour.) Merr., Portulaca oleracea L., and Artemisia lavandulaefolia DC. 
Table 4. Comparison of weed species exposed to different mulch treatments.

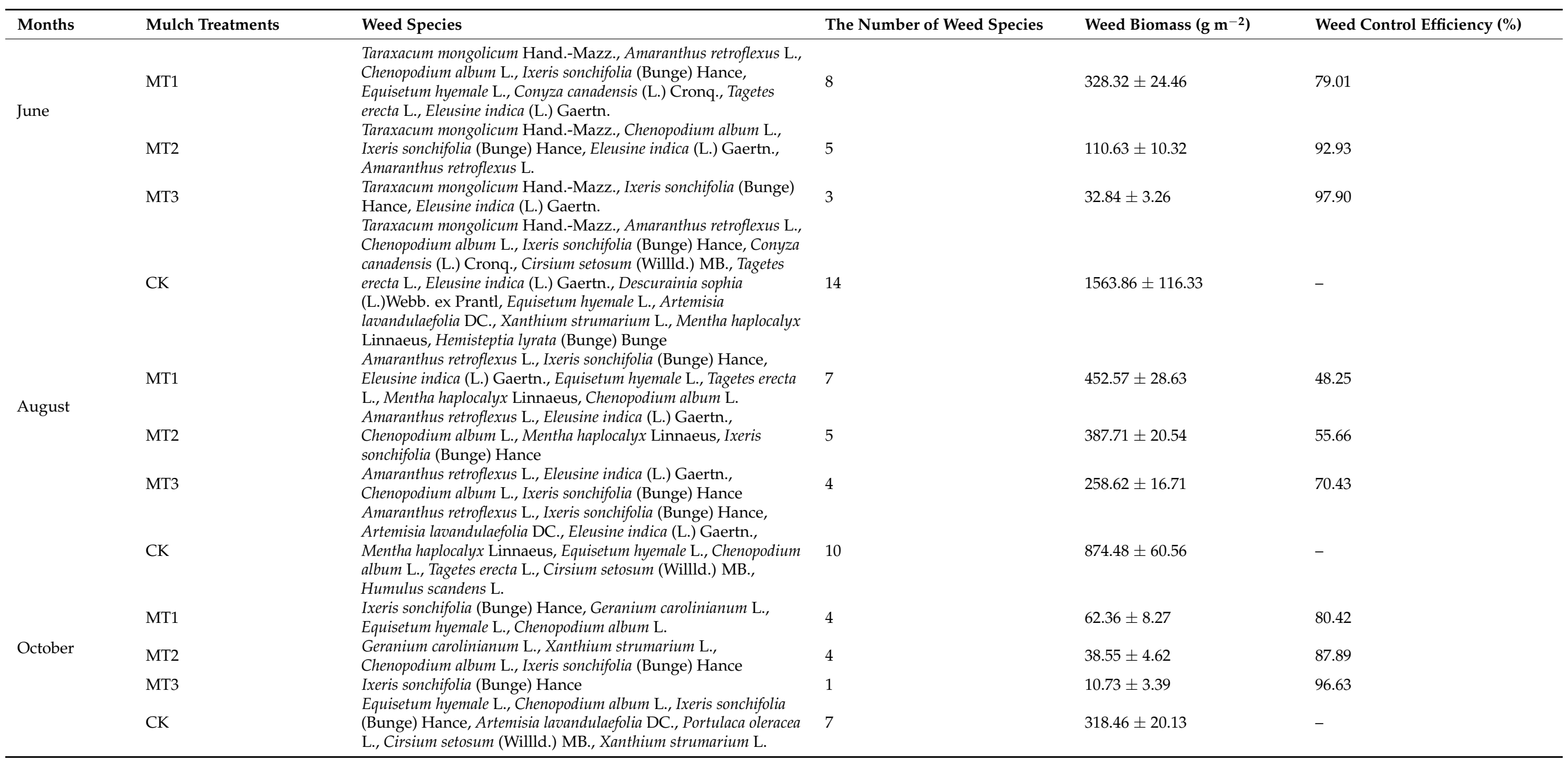




\subsection{Effect of Mulching Thickness on Leaf Nutrients and Chlorophyll Content}

The monthly dynamics of the leaf $\mathrm{N}$ content in soil exposed to different mulch treatments are shown in Figure 5a. In CK, the leaf $\mathrm{N}$ content first decreased in June, then increased from July to August, and finally decreased sharply in September and October. The dynamic trend for the leaf $\mathrm{N}$ content in the other treatment groups was an initial increase followed by a decrease. The monthly variation in the leaf $\mathrm{N}$ content in all treatments was significant. There were also significant differences in the leaf $\mathrm{N}$ content among different treatments from June to October. The average leaf N content of MT3, MT2, and MT1 was $14.03 \%, 12.28 \%$, and $8.39 \%$ higher, respectively, than that of CK.
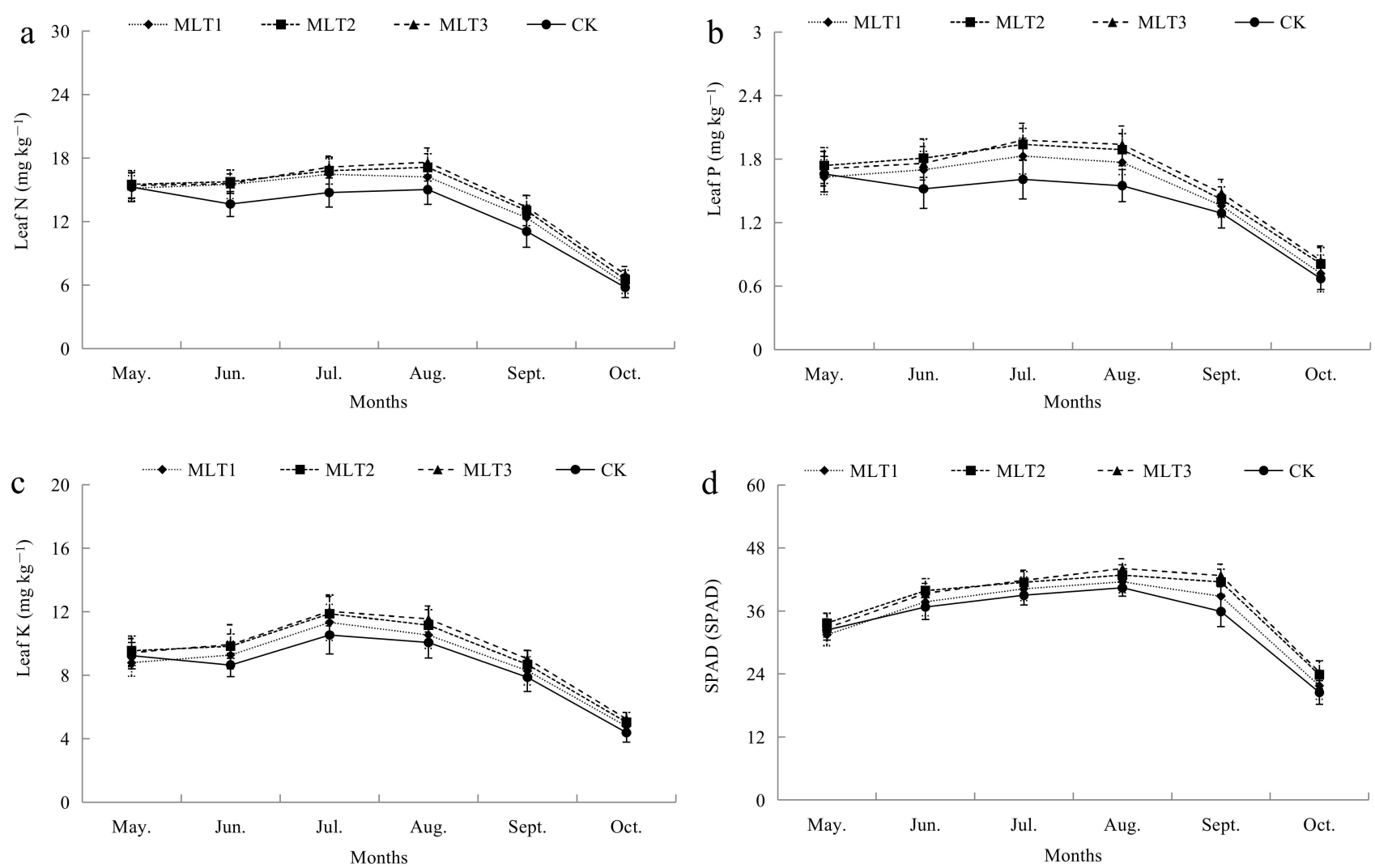

Figure 5. Variation in leaf nutrient contents among different treatment groups during the growth period: (a) leaf $\mathrm{N}$; (b) leaf $\mathrm{P}$; (c) leaf $\mathrm{K}$; (d) SPAD.

Figure $5 \mathrm{~b}$ shows the monthly dynamics of the leaf $\mathrm{P}$ content with different mulch treatments. The dynamic trend for the leaf P content in MT1, MT2, and MT3 was similar; that is, an initial slight increase from May to July and then a decrease from August to October. In CK, the trend was a decrease from May to June, then a stable period from July to August, and finally a rapid decrease in September and October. The highest leaf $\mathrm{P}$ content appeared in July for MT1, MT2, and MT3, while for CK, it appeared in May, and the lowest leaf $\mathrm{P}$ content was in October for all groups. The average leaf P content of MT3, MT2, and MT1 was $16.99 \%, 15.78 \%$, and $8.55 \%$ higher, respectively, than that of CK.

Figure $5 \mathrm{c}$ shows the monthly dynamics of the leaf $\mathrm{K}$ content in soil exposed to different mulch treatments. There were significant differences in the leaf $\mathrm{K}$ content not only in different months, but also with different treatments. The highest leaf $\mathrm{K}$ content appeared in July for MT1, MT2, MT3, and CK: $11.33 \pm 1.14,11.87 \pm 1.18,12.02 \pm 1.25$, and $10.53 \pm$ $1.20 \mathrm{mg} \mathrm{g}^{-1}$, respectively. The minimum leaf $\mathrm{K}$ content occurred in October for MT1, MT2, MT3, and CK: $4.78 \pm 0.49,5.03 \pm 0.62,5.24 \pm 0.54$, and $4.37 \pm 0.59 \mathrm{mg} \mathrm{g}^{-1}$, respectively. The average leaf K content of the MT3, MT2, and MT1 treatments was $12.79 \%, 10.61 \%$, and $4.45 \%$ higher, respectively, than that of CK. 
Figure $5 \mathrm{~d}$ presents the monthly dynamics of SPAD in soil exposed to these mulch treatments. There were significant differences in SPAD both in different months and with different treatments. The four treatments showed similar dynamic trends; that is, an initial increase from May to August and then a decrease from September to October. The average value of SPAD in MT3, MT2, and MT1 was $9.87 \%, 8.96 \%$, and $3.24 \%$ higher, respectively, than that in CK.

\subsection{Effect of Mulching Thickness on the Nut Yield and Quality Traits}

The nut yield and quality traits varied in soil exposed to different mulch treatments. The values of these parameters are shown in Table 5.

Table 5. Comparison of weed species exposed to different mulch treatments.

\begin{tabular}{lllll}
\hline Nut Traits & MT1 & MT2 & MT3 & CK \\
\hline Individual-plant & $1027.06 \pm 151.71$ & $1045.26 \pm 146.41$ & $1019.50 \pm 144.15$ & $1001.40 \pm 144.54$ \\
yield (g/tree) & $\mathrm{A}$ & $\mathrm{A}$ & $\mathrm{A}$ & $\mathrm{A}$ \\
$L(\mathrm{~mm})$ & $19.92 \pm 2.87 \mathrm{AB}$ & $20.47 \pm 2.23 \mathrm{~A}$ & $20.71 \pm 3.07 \mathrm{~A}$ & $19.22 \pm 2.28 \mathrm{~B}$ \\
$W(\mathrm{~mm})$ & $17.96 \pm 2.34 \mathrm{~A}$ & $18.18 \pm 2.11 \mathrm{~A}$ & $17.78 \pm 1.93 \mathrm{AB}$ & $16.97 \pm 1.90 \mathrm{~B}$ \\
$T(\mathrm{~mm})$ & $16.77 \pm 2.29 \mathrm{AB}$ & $16.97 \pm 1.95 \mathrm{~A}$ & $16.53 \pm 2.08 \mathrm{AB}$ & $16.05 \pm 1.70 \mathrm{~B}$ \\
$D(\mathrm{~mm})$ & $18.13 \pm 2.15 \mathrm{~A}$ & $18.45 \pm 1.76 \mathrm{~A}$ & $18.23 \pm 2.13 \mathrm{~A}$ & $17.34 \pm 1.70 \mathrm{~B}$ \\
$V\left(\mathrm{~cm}^{3}\right)$ & $3.25 \pm 1.11 \mathrm{~A}$ & $3.38 \pm 0.93 \mathrm{~A}$ & $3.29 \pm 1.01 \mathrm{~A}$ & $2.81 \pm 0.82 \mathrm{~B}$ \\
$\varnothing$ & $0.92 \pm 0.08 \mathrm{~A}$ & $0.91 \pm 0.07 \mathrm{AB}$ & $0.89 \pm 0.06 \mathrm{~B}$ & $0.91 \pm 0.06 \mathrm{AB}$ \\
$N S I$ & $0.88 \pm 0.12 \mathrm{~A}$ & $0.86 \pm 0.11 \mathrm{AB}$ & $0.84 \pm 0.09 \mathrm{~B}$ & $0.87 \pm 0.09 \mathrm{AB}$ \\
$N M(\mathrm{~g})$ & $2.40 \pm 0.78 \mathrm{~A}$ & $2.56 \pm 0.73 \mathrm{~A}$ & $2.45 \pm 0.69 \mathrm{~A}$ & $2.08 \pm 0.63 \mathrm{~B}$ \\
KM $(\mathrm{g})$ & $0.95 \pm 0.29 \mathrm{~A}$ & $1.00 \pm 0.30 \mathrm{~A}$ & $0.95 \pm 0.29 \mathrm{~A}$ & $0.82 \pm 0.21 \mathrm{~B}$ \\
$P K(\%)$ & $40.28 \pm 6.43 \mathrm{~A}$ & $40.02 \pm 9.93 \mathrm{~A}$ & $38.96 \pm 7.69 \mathrm{~A}$ & $39.69 \pm 5.43 \mathrm{~A}$ \\
$C P C(\%)$ & $21.16 \pm 1.15 \mathrm{~A}$ & $22.18 \pm 1.15 \mathrm{~A}$ & $21.70 \pm 1.00 \mathrm{~A}$ & $20.89 \pm 1.45 \mathrm{~A}$ \\
SSC $(\%)$ & $4.11 \pm 0.18 \mathrm{~A}$ & $4.23 \pm 0.15 \mathrm{~A}$ & $4.18 \pm 0.11 \mathrm{~A}$ & $4.05 \pm 0.24 \mathrm{~A}$ \\
$C F C(\%)$ & $60.29 \pm 1.68 \mathrm{AB}$ & $61.87 \pm 1.41 \mathrm{~A}$ & $60.63 \pm 1.25 \mathrm{AB}$ & $59.82 \pm 1.89 \mathrm{~B}$ \\
\hline Note: Capital letters represent significant differences $(p<0.05)$ among treatments. &
\end{tabular}

The average values of $D, V, N M$, and $K M$ were significantly lower in CK in soil exposed to mulch treatments. The highest average $L$ value appeared in MT3, and this was $7.75 \%$ higher than that of $C K$. The highest average $D$, average $V$, average $N M$, and average KM values all appeared in MT2. These were $6.40 \%, 20.28 \%, 23.08 \%$, and $21.95 \%$ higher than the values in CK, respectively. Although there were significant differences in NM and KM between soil exposed or not to mulch treatments, the difference in $P K$ was not significant. MT1 treatment had the highest $P K$, followed by MT2, CK, and MT3. Sphericity and shape index are the main indicators of nut shape, and these variables are determined by nut dimensions. According to Milošević and Milošević [28], an NSI value of 0.84 indicates that the hazelnut shape is conical, and an NSI value above 0.86 indicates that the hazelnut shape is globular. In this study, the average nut sphericity and nut shape index values were highest in MT1, which means that the nuts in MT1 were rounder than in other treatments. There were no significant differences in the plant yield, $C P C$, or SSC among these treatment groups. The individual plant yield, CPC, and SSC were the highest in MT2, 4.38\%, 6.18\%, and $4.44 \%$ higher than the values in CK, respectively. The CFC of MT2 was significantly higher than that of $\mathrm{CK}$.

\section{Discussion}

\subsection{Effect of Mulching on Soil Physico-Chemical and Biological Properties}

Soil temperature is a key environmental factor that has an impact on crop growth and development by regulating water absorption and nutrient uptake in root zones [29]. Mulches alter the soil temperature, which affects the thermal regime of a soil [30]. However, the effect of mulches on the soil temperature varies depending on the capacity of the mulching materials to reflect and transmit solar energy [31]. Organic mulches can reduce the maximum soil temperature, but increase the minimum soil temperature, while they 
significantly reduce the soil temperature [8]. The results of a mulching study conducted on the Loess Plateau showed that daily mean soil temperatures in soil treated with mulch at a depth of $10 \mathrm{~cm}$ were lower in warmer periods by $0-4{ }^{\circ} \mathrm{C}$ and higher in colder periods by $0-2{ }^{\circ} \mathrm{C}$ compared with non-mulched soil [32]. Similarly, in our study, SMS mulching measures can efficiently regulate the soil temperature by reducing it in warm weather and increasing it in cold weather. However, the regulation ability of SMS varies with the mulching thickness and soil depth. SMS forms a temperature isolation layer on the soil surface owing to its high reflectivity and low thermal diffusivity, which can effectively reduce fluctuations in the soil temperature.

Soil moisture is also considered to be an important factor affecting plant growth and development, and even a small change in soil water storage could affect crop productivity [33]. A large number of previous studies have confirmed that mulching can effectively conserve soil water by reducing soil evaporation [29]. Mulching has a positive impact on the soil water content that depends on the type of mulching materials and thickness of mulching used [34]. Some studies have shown that the mulch thickness is more important than the texture of the mulch for evaporation suppression, and thicker mulch prevents soil water evaporation more effectively. Moreover, studies have shown that mineral or organic mulches must have a critical thickness to effectively reduce soil evaporation, and the crop yield and water use efficiency can be reduced if the mulching thickness is excessive [35]. McMillen [36] compared the soil water retention capacity of three organic mulching materials with different mulching thickness. The results showed that treatment with $10 \mathrm{~cm}$ thick mulch increased the soil moisture by over 10\% compared with bare soil, while $15 \mathrm{~cm}$ thick mulching treatment did not significantly reduce soil evaporation further. The results of this study are consistent with the previous research conclusion, that is, $10 \mathrm{~cm}$ thick mulch had a strong water holding capacity throughout the field experiment period. The soil moisture content of MT2 was significantly higher than that of CK in all three soil depths during the rainy season. Evaporation and drainage were the main factors that reduced the soil moisture content in the soil profile of $0-30 \mathrm{~cm}$ in the rainy season, and mulching can conserve the soil moisture for longer periods than bare soil [37]. With an increase in the soil depth, the difference in soil moisture among different treatments decreased.

The effect of mulching on the soil bulk density varies depending on the soil properties, mulch material used, climatic conditions, and land use. Mulching increases the soil bulk density when conventional tillage is used, but can also reduce it by adding organic matter to the soil. Whether there is an increase or decrease in the soil bulk density depends on the specific situation [8]. Massaccesi et al. [38] supports the idea that the soil bulk density tends to increase with the application of organic mulch combined with no-tillage practices. In 2015, Kader et al. showed that the soil bulk density following straw mulching was lower than at a depth of $0-30 \mathrm{~cm}$ compared with that of bare soil; however, the reverse trend was found in 2016 [37]. Ni et al. [39] reported non-significant results for the effects of mulching on the soil bulk density at a depth of $0-10 \mathrm{~cm}$. The results of this study demonstrate that the soil bulk density tended to increase as the mulching thickness increased, but there was no significant difference between mulching and non-mulch treatments. Soil porosity is influenced by the agronomic practices implemented, and it decreases with the soil depth [40,41]. Nzeyimana et al. [42] conducted a two-year mulching experiment to quantify the effects of different organic mulches on soil properties, and the results showed that the application of mulch had a positive impact on the soil porosity. However, the effects of the interactions between the type of mulch and type of soil were site-specific. In our study, there was no significant difference in soil porosity among the different mulch treatments. SMS usually required a long time to completely mineralize [43], thus it may take a longer time to improve soil structure when SMS is used as a mulching material.

A significant loss in soil nutrients occurs within 1-2 years of plastic mulching, probably owing to temperature-induced accelerated biodegradation [44], which is closely linked and entangled with an increasing $\mathrm{C} / \mathrm{N}$ metabolism [45]. However, when the soil carbon pool is maintained by organic matter input, the SOM content remains stable [8]. A study by 
Pal and Mahajan [46] revealed that higher soil nutrient contents can be achieved through the application of an optimal level of organic mulch (pine-needle mulch). Similarly, our study showed that the use of SMS mulch can significantly increase the soil nutrient content compared with soil not treated with mulch. Although the highest average values of SOM, $\mathrm{AH}-\mathrm{N}, \mathrm{AK}$, and AP were observed in MT3, there were no significant difference in soil nutrient contents between MT2 and MT3. This may be owing to the fact that nutrient release by mineralization requires an appropriate quantity of SMS mulch. The monthly dynamics of soil nutrients are strongly affected by both the mineralization rate and plant uptake and utilization. In this experiment, higher contents of AK and AP were found in soil exposed to mulch treatment. Similar results were also reported in straw mulch by Xia [47] and Zhao [48]. The high AK content found in MT2 and MT3 may be due to the fact that $\mathrm{K}$ exists in SMS (plant tissue) in the free ionic form and is easily leached into the soil. However, the high content of AP in MT2 and MT3 may be related to the accumulation of P in the soil. The demand for P decreases in the nut maturity stage, while soil microorganisms accelerate the mineralization process and release a large amount of AP into the soil with mulch treatments. Microbial communities are closely associated with soil nutrients and strongly influence the soil quality.

Soil enzymes mainly come from the process of microbial metabolism and are closely related to the composition, abundance, and activity of soil microbial communities. Soil enzymes are also regulated by the demand for substrates as well as by the substrate availability [49]. Qu and Feng [50] found that straw mulching increased the activity levels of soil urease, invertase, and acid phosphatase. Similarly, this study showed that SMS mulch can effectively increase soil enzyme activities compared with soil not treated with mulch. The increase in soil enzyme activities following SMS mulching treatment might owing to the increased carbon sources and the improved soil quality. Soil enzymatic activity levels followed the order MT3 $\approx$ MT2 $>$ MT1 $>$ CK. Sufficient, but not excessive application of SMS was beneficial for the carbon source utilization of fast-growing microorganisms [51]. In this study, the use of a moderate mulching thickness may be a better way to improve soil enzymatic activity from a cost perspective.

\subsection{Effect of Mulching on Weed Suppression}

Weed control is one of the biggest challenges in the farming system [52]. As the growth of weeds depends on the availability of light and because light can only penetrate soil to a depth of up to a few centimeters, a certain thickness $(>5 \mathrm{~cm})$ of organic mulch is considered to effectively suppress weed germination through the exclusion of light or by acting as a physical barrier [53]. In our study, SMS mulching decreased light penetration and inhibited the germination of weed seeds in the early stage. At this stage, the weed control efficiency was as high as $79.01-97.90 \%$ for mulch treatment. With the arrival of the rainy season, alien weed seeds emerged easily from thin or damaged parts of the mulch layers, resulting in a weakened inhibition effect of mulching on weeds. The weed control efficiency decreased to $48.25-70.43 \%$. This can largely be explained by the positive effect of soil moisture on weed emergence. In addition, SMS decomposition resulted in a decrease in soil cover during the growing season and may also have positively affected weed emergence [54]. With a continuous decrease in temperature, some annual weeds completed their life cycle, resulting in a significant decrease in weed biomass in October. Additionally, the weed control efficiency increased to $80.42-96.63 \%$ in the nut maturity stage.

Previous studies indicated that a certain amount of organic mulch is needed for weed suppression $[17,18]$. Thankamani et al. [18] suggested that the application of $6 \mathrm{t} \cdot \mathrm{ha}^{-1}$ of paddy straw along with $7.5 \mathrm{t} \cdot \mathrm{ha}^{-1}$ of green leaf mulch at 45 and 90 days after planting could led to a higher weed control efficiency and a greater yield, as well as economic return. Taak et al. [55] evaluated the effects of mulching and herbicide treatments on weed control and found that straw mulching treatment $\left(15 \mathrm{t} \cdot \mathrm{ha}^{-1}\right)$ not only effectively controls weeds, but is also associated with the highest crop yield. Weed emergence and biomass decreased with increasing amounts of organic mulch [54]. The results of our study also support the 
conclusion that SMS with a thickness of more than $10 \mathrm{~cm}$ is associated with a better weed control efficiency.

\subsection{Effect of Mulching on the Leaf Nutrient and Chlorophyll Contents}

Leaf tissue is most commonly used for nutrient analysis because it is the one of the most active sites of plant metabolism. The leaf nutrient analysis provides an indication of plant nutritional status that can reflect plant health. It is necessary to determine whether or not a plant is well nourished, as having an adequate nutritional state is a determining factor in the productivity/yield of any plant [21]. In our study, all SMS mulch treatments effectively increased the leaf nutrient $(\mathrm{N}, \mathrm{P}$, and $\mathrm{K})$ and chlorophyll contents, while the leaf $\mathrm{N}, \mathrm{P}, \mathrm{K}$, and chlorophyll contents of MT2 and MT3 were significantly improved. In the short-term experiment of one year, the leaf nutrient content decreased twice. The first decrease occurred in June when the nutrients of newborn leaves were easily leached out by rainfall with the arrival of the rainy season. The second decline occurred from September to October when the leaf N, P, and K contents began to be transferred to other vigorous organs (such as fruit), and the leaves entered the senescence stage. The chlorophyll content of leaves showed a trend involving an initial increase, following by a decrease. With leaf senescence, the chlorophyll content also reduced. Although studies about the effect of organic mulching on leaf nutrients are still insufficient, some existing literature supports the idea that organic mulching can improve the leaf nutrient level. Pal and Mahajan [46] found a significantly higher leaf $\mathrm{K}$ content in Stevia rebaudiana Bertoni following the application of pine-needle mulching at a level of $15 \mathrm{t} \cdot \mathrm{ha}^{-1}$ compared with other treatments. Namaghi et al. [56] also found higher levels of $\mathrm{P}$ and $\mathrm{Mg}$ in barley-straw-mulched pistachio leaves. Kader et al. [37] reported that straw mulching significantly improved the leaf chlorophyll content of soybean compared with bare soil. The higher leaf nutrient and chlorophyll contents may have been due to the suitable soil microclimate created by organic mulching, which promoted root growth, and thus increased the absorption of soil nutrients [37]. In addition, the nutrients of organic matter were gradually released into the soil after organic mulching and significantly increased the available soil nutrients [56].

\subsection{Effect of Mulching on Fruit Yield and Quality}

Although previous studies have reported the effect of organic mulching on the fruit yield and quality, there has been no consistent conclusion in this regard owing to differences in mulching materials, mulching practices, climatic conditions, research objects, and so on. Some studies have shown that organic mulching can markedly increase the fruit yield with no significant effect on fruit quality [57]. Some studies have observed that organic mulching has a significant positive effect on both fruit yield and quality. Ye et al. [58] showed that mulching significantly increased the yield and quality of Camellia oleifera, which was consistent with previous results for apple trees [59], peach trees [57], jujube trees [60], and pistachio trees [56]. The present study suggests that all mulch treatments were associated with an increasing trend in nut yield and quality compared with the nonmulching treatment. All mulch treatments were associated with the production of nuts with significantly higher geometric mean diameters and volumes than those produced with CK. A higher variability in growth of individual fruits is mainly due to the fruit-tofruit competition for nutrients and resources [61]. SMS mulch increased the availability of soil nutrients; therefore, the nuts produced in plots treated with mulch were larger. The larger nut size correspondingly increased the nut mass and kernel mass. These two important parameters of nuts were significantly improved under mulch treatments. The nut sphericity and nut shape index were significantly lower in MT3 than in MT1, which may be due to the rapid growth in the longitudinal diameter when the nutrient supply was relatively sufficient. Variations in fruit size and shape under different mulch treatments were also reported by Ye et al. [58]. Although our research revealed that short-term SMS mulching had no obvious advantage in terms of increasing the individual plant yield, CPC, or SSC, MT2 did effectively increase the CFC of nuts. The non-significant increase in nut 
yield may have been due to the following factors: (1) organic mulch could improve soil hydro-thermal regimes [62]; (2) organic mulch could increase the soil nutrient content by organic matter decomposition; (3) organic mulch could prevent excessive weed growth; and (4) organic mulch could improve the nutrient status and photosynthetic capacity of leaves [56]. Variations in the CPC, SSC, and CFC of nuts among mulch treatments indicated that the formation of fruit quality is a complex physiological and biochemical process. This process is closely related to the transport, allocation, conversion, and metabolism of carbohydrates, which is strongly influenced not only by biological factors, but also by environmental factors [63]. The soil moisture status is often considered to be a critical factor affecting oil synthesis. When a water deficit occurs, it will lead to a decrease in the crude fat content of fruit [64].

\section{Conclusions}

SMS mulching was found to influence soil fertility, weed control, leaf quality, and nut traits. The effects varied depending on the mulching thickness used. Although SMS mulching had no significant effect on soil structure in the short-term experiment, it significantly improved the topsoil nutrient availability. SMS mulching also decreased the number of weed species and weed biomass obviously. Short-term SMS mulching had no obvious advantages in terms of increasing the individual plant yield, CPC, or SSC, but it increased the nut size, nut and kernel mass, as well as CFC to a certain extent. The results showed that SMS with a $10 \mathrm{~cm}$ thickness could be used for mulching practices.

While SMS mulching is known to improve soil fertility and nut quality in the short term, its long-term effects require further research. In particular, more research is needed to understand the effects of SMS mulching on photosynthetic efficiency and water consumption, which are fundamental factors in the shaping of the characteristics of nuts over an extended period of time.

Author Contributions: Conceptualization, Z.M., Y.-Q.Z., J.-X.Q., and S.-C.S.; methodology, Z.M., Y.Q.Z., and L.-J.W.; data curation, Z.M., Y.-Q.Z., and G.-L.H.; software, Z.M.; formal analysis, Z.M. and Y.-Q.Z.; project administration, S.-C.S. and J.-X.Q.; supervision, L.-J.W., X.-Q.G., and Q.B.; writingoriginal draft, Z.M. and Y.-Q.Z.; writing-review and editing, G.-L.H., X.-Q.G., S.-C.S., and J.-X.Q. All authors have read and agreed to the published version of the manuscript.

Funding: This research was funded by Key techniques of improved variety breeding and Cultivation for hazelnut [2011-03].

Institutional Review Board Statement: Not applicable.

Informed Consent Statement: Not applicable.

Data Availability Statement: Data sharing not applicable.

Conflicts of Interest: The authors declare no conflict of interest.

\section{References}

1. Food and Agriculture Organization of the United Nation, Agricultural Data. Available online: http://www.fao.org/faostat/en/ \#data/QC (accessed on 17 January 2019).

2. Alasalvar, C.; Shahidi, F.; Liyanapathirana, C.M.; Ohshima, T. Turkish Tombul Hazelnut (Corylus avellana L.). 1. Compositional Characteristics. J. Agric. Food Chem. 2003, 51, 3790-3796. [CrossRef] [PubMed]

3. Felbinger, C.; Kutzsche, F.; Mnkediek, S.; Fischer, M.J.F.C. Genetic profiling: Differentiation and identification of hazelnut cultivars (Corylus avellana L.) using RAPD-PCR. Food Control. 2019, 107, 106791. [CrossRef]

4. Jabran, K. Mulches for Enhancing Biological Activities in Soil. In Role of Mulching in Pest Management and Agricultural Sustainability; Ömer Halisdemir University Press: Niğde, Turkey, 2019; pp. 41-46. ISBN 978-3-030-22300-7.

5. Gao, H.; Yan, C.; Liu, Q.; Ding, W.; Chen, B.; Li, Z. Effects of plastic mulching and plastic residue on agricultural production: A meta-analysis. Sci. Total Environ. 2019, 651, 484-492. [CrossRef] [PubMed]

6. Qi, Y.; Yang, X.; Pelaez, A.M.; Huerta Lwanga, E.; Beriot, N.; Gertsen, H.; Garbeva, P.; Geissen, V. Macro- and micro-plastics in soil-plant system: Effects of plastic mulch flm residues on wheat (Triticum aestivum) growth. Sci. Total Environ. 2018, 645, 1048-1056. [CrossRef] 
7. López, R.; Burgos, P.; Hermoso, J.M.; Hormaza, J.I.; González-Fernández, J. Long term changes in soil properties and enzyme activities after almond shell mulching in avocado organic production. Soil Tillage Res. 2014, 143, 155-163. [CrossRef]

8. Kader, M.A.; Senge, M.; Mojid, M.A.; Ito, K. Recent advances in mulching materials and methods for modifying soil environment. Soil Tillage Res. 2017, 168, 155-166. [CrossRef]

9. Royse, D.J.; Baars, J.; Tan, Q. Current Overview of Mushroom Production in the World: Technology and Applications; Wiley-Blackwell Press: Hoboken, NJ, USA, 2017; pp. 5-13. ISBN 978-1-119-14941-5.

10. Hanafi, F.H.M.; Rezania, S.; Taib, S.M.; Din, M.F.M.; Yamauchi, M.; Sakamoto, M.; Hara, H.; Park, J.; Ebrahimi, S.S. Environmentally sustainable applications of agro-based spent mushroom substrate (SMS): An overview. J. Mater. Cycles Waste Manag. 2018, 20, 1383-1396. [CrossRef]

11. Nakatsuka, H.; Oda, M.; Hayashi, Y.; Tamura, K. Effects of fresh spent mushroom substrate of Pleurotus ostreatus on soil micromorphology in Brazil. Geoderma 2016, 269, 54-60. [CrossRef]

12. Li, Q.; Wang, M.; Fu, Q.; Li, T.; Liu, D.; Hou, R.; Li, H.; Cui, S.; Ji, Y. Short-term influence of biochar on soil temperature, liquid moisture content and soybean growth in a seasonal frozen soil area. J. Environ. Manag. 2020, 266, 110609. [CrossRef]

13. Shan, L.; Qi-Quan, L.I.; Chang-Quan, W.; Bing, L.I.; Xue-Song, G.; Yi-Ding, L.I.; De-yong, W. Spatial variability of soil bulk density and its controlling factors in an agricultural intensive area of Chengdu Plain, Southwest China. J. Integr. Agric. 2019, 18, 290-300. [CrossRef]

14. Khan, S.; Mulvaney, R.; Hoeft, R. A Simple Soil Test for Detecting Sites that are Nonresponsive to Nitrogen Fertilization. Soil Sci. Soc. Am. J. 2001, 65, 1751-1760. [CrossRef]

15. Carson, P.L. Recommended potassium test. In Recommended Chemical Soil Test Procedures for the North Central Region; Dahnke, W.C., Ed.; North Dakota Agricultural Experiment Station: Fargo, ND, USA, 1980; pp. 17-18.

16. Ge, Y.; Wang, Q.; Wang, L.; Liu, W.; Liu, X.; Huang, Y.; Christie, P. Response of soil enzymes and microbial communities to root extracts of the alien Alternanthera philoxeroides. Arch. Agron. Soil Sci. 2018, 64, 708-717. [CrossRef]

17. Singh, R.; Brar, S.; Walia, U.S. Comparative efficiency of herbicides for weed control in Chickpea (Cicer arietinum L.). Crop Res. 2000, 19, 1-5.

18. Thankamani, C.K.; Kandiannan, K.; Hamza, S.; Saji, K.V. Effect of mulches on weed suppression and yield of ginger (Zingiber officinale Roscoe). Sci. Hortic. 2016, 207, 125-130. [CrossRef]

19. Dong, Q.; Dang, T.; Guo, S.; Hao, M. Effect of different mulching measures on nitrate nitrogen leaching in spring maize planting system in south of Loess Plateau. Agric. Water Manag. 2019, 213, 654-658. [CrossRef]

20. Debnath, A.; Barrow, N.J.; Ghosh, D.; Malakar, H. Diagnosing p status and p requirement of tea (camellia sinensis L.) by leaf and soil analysis. Plant Soil 2011, 341, 309-319. [CrossRef]

21. Guimarães, Z.T.; Dos Santos, V.A.; Nogueira, W.L.; de Almeida Martins, N.O.; Ferreira, M.J. Leaf traits explaining the growth of tree species planted in a Central Amazonian disturbed area. For. Ecol. Manag. 2018, 430, 618-628. [CrossRef]

22. Martinez, F.; Oliveira, J.A.; Calvete, E.O.; Palencia, P. Influence of growth medium on yield, quality indexes and SPAD values in strawberry plants. Sci. Hortic. 2017, 217, 17-27. [CrossRef]

23. Hosseinpour, A.; Seifi, E.; Javadi, D.; Ramezanpour, S.S.; Molnar, T.J. Nut and kernel characteristics of twelve hazelnut cultivars grown in Iran. Sci. Hortic. 2013, 150, 410-413. [CrossRef]

24. Wang, W.; Jung, J.; McGorrin, R.J.; Traber, M.G.; Leonard, S.W.; Cherian, G.; Zhao, Y. Investigation of drying conditions on bioactive compounds, lipid oxidation, and enzyme activity of Oregon hazelnuts (Corylus avellana L.). Food Sci. Technol. 2018, 90, 526-534. [CrossRef]

25. Luo, D.; Shi, Y.J.; Song, F.H.; Zheng, W.U.; Ablat, M.; Cheng, L.I. Spatial Distribution Characteristics of Fine roots in Monoculture System of Corylus heterophylla $\times$ Corylus avellana. For. Res. 2019, 32, 81-89. [CrossRef]

26. Burns, R.G.; DeForest, J.L.; Marxsen, J.; Sinsabaugh, R.L.; Stromberger, M.E.; Wallenstein, M.D.; Weintraub, M.N.; Zoppini, A. Soil enzymes in a changing environment: Current knowledge and future directions. Soil Biol. Biochem. 2013, 58, 216-234. [CrossRef]

27. Veres, Z.; Kotroczó, Z.; Fekete, I.; Tóth, J.A.; Lajtha, K.; Townsend, K.; Tóthmérész, B. Soil extracellular enzyme activities are sensitive indicators of detrital inputs and carbon availability. Appl. Soil Ecol. 2015, 92, 18-23. [CrossRef]

28. Milošević, T.; Milošević, N. Determination of size and shape features of hazelnuts using multivariate analysis. Acta Sci. Pol. Hortorum Cultus 2017, 16, 49-61. [CrossRef]

29. Liao, Y.; Cao, H.X.; Xue, W.K.; Liu, X. Effects of the combination of mulching and deficit irrigation on the soil water and heat, growth and productivity of apples. Agric. Water Manag. 2021, 243, 106482. [CrossRef]

30. Pramanik, P.; Bandyopadhyay, K.K.; Bhaduri, D.; Bhattacharyya, R.; Aggarwal, P. Effect of mulch on soil thermal regimes-A review. Int. J. Agric. Environ. Biotechnol. 2015, 8, 645. [CrossRef]

31. Lamont, W.J. Plastics: Modifying the microclimate for the production of vegetable crops. Horttechnology 2005, 15, 477-481. [CrossRef]

32. Zhang, S.; Lovdahl, L.; Grip, H.; Tong, Y.; Yang, X.; Wang, Q. Effects of mulching and catch cropping on soil temperature, soil moisture and wheat yield on the Loess Plateau of China. Soil Tillage Res. 2009, 102, 78-86. [CrossRef]

33. Liu, Y.; Yang, S.; Li, S.; Chen, X.; Chen, F. Growth and development of maize (Zea mays L.) in response to different field water management practices: Resource capture and use efficiency. Agric. For. Meteorol. 2010, 150, 606-613. [CrossRef]

34. Thakur, M.; Kumar, R. Mulching: Boosting crop productivity and improving soil environment in herbal plants. J. Appl. Res. Med. Aromat. Plants 2021, 20, 100287. [CrossRef] 
35. Jones, H.; Black, T.A.; Jassal, R.S.; Nesic, Z.; Johnson, M.S.; Smukler, S. Characterization of shortwave and longwave properties of several plastic film mulches and their impact on the surface energy balance and soil temperature. Solar Energy 2021, 214, 457-470. [CrossRef]

36. Mcmillen, M. The Effect of Mulch Type and Thickness on the Soil Surface Evaporation Rate. Available online: https:// digitalcommons.calpoly.edu (accessed on 1 June 2013).

37. Kader, M.A.; Nakamura, K.; Senge, M.; Mojid, M.A.; Kawashima, S. Soil hydro-thermal regimes and water use efficiency of rain-fed soybean (Glycine max) as affected by organic mulches. Agric. Water Manag. 2019, 223, 105707. [CrossRef]

38. Massaccesi, L.; Rondoni, G.; Tosti, G.; Conti, E.; Agnelli, A. Soil functions are affected by transition from conventional to organic mulch-based cropping system. Appl. Soil Ecol. 2020, 153, 103639. [CrossRef]

39. Ni, X.; Song, W.; Zhang, H.; Yang, X.; Wang, L. Effects of Mulching on Soil Properties and Growth of Tea Olive (Osmanthus fragrans). PLoS ONE 2016, 11, e0158228. [CrossRef]

40. Al-Shammary, A.A.G.; Kouzani, A.; Gyasi-Agyei, Y.; Gates, W.; Rodrigo-Comino, J. Effects of solarisation on soil thermal-physical properties under different soil treatments: A review. Geoderma 2020, 363, 114137. [CrossRef]

41. Pires, L.F.; Borges, J.A.; Rosa, J.A.; Cooper, M.; Heck, R.J.; Passoni, S.; Roque, W.L. Soil structure changes induced by tillage systems. Soil Tillage Res. 2017, 165, 66-79. [CrossRef]

42. Nzeyimana, I.; Hartemink, A.E.; Ritsema, C.; Stroosnijder, L.; Lwanga, E.H.; Geissen, V. Mulching as a strategy to improve soil properties and reduce soil erodibility in coffee farming systems of Rwanda. CATENA 2017, 149, 43-51. [CrossRef]

43. Zanella, A.; Ponge, J.F.; Guercini, S.; Rumor, C.; Nold, F.; Sambo, P.; Gobbi, V.; Schimmer, C.; Chaabane, C.; Mouchard, M.L. Humusica 2, article 16: Techno humus systems and recycling of waste. Appl. Soil Ecol. 2017, 122, 220-236. [CrossRef]

44. Moreno, M.M.; Moreno, A. Effect of different biodegradable and polyethylene mulches on soil properties and production in a tomato crop. Sci. Hortic. 2008, 116, 256-263. [CrossRef]

45. Steinmetz, Z.; Wollmann, C.; Schaefer, M.; Buchmann, C.; David, J.; Troeger, J.; Munoz, K.; Froer, O.; Schaumann, G.E. Plastic mulching in agriculture. Trading short-term agronomic benefits for long-term soil degradation? Sci. Total Environ. 2016, 550, 690-705. [CrossRef]

46. Pal, P.K.; Mahajan, M. Tillage system and organic mulch influence leaf biomass, steviol glycoside yield and soil health under sub-temperate conditions. Ind. Crops Prod. 2017, 104, 33-44. [CrossRef]

47. Study on the Soil Ecological Effects and Physiological Response in Different Groundcover Pear Tree. Available online: https: / / kns.cnki.net/ kns8 (accessed on 1 January 2013).

48. Study on Soil Ecological Effect of Different Mulching Measures in Tea Garden. Available online: https://kns.cnki.net/kns8 (accessed on 12 June 2006).

49. Olander, L.P.; Vitousek, P.M. Regulation of soil phosphatase and chitinase activityby N and P availability. Biogeochemistry 2000, 49, 175-190. [CrossRef]

50. Qu, Y.; Feng, B.L. Straw mulching improved yield of field buckwheat (Fagopyrum) by increasing water-temperature use and soil carbon in rain-fed farmland. Acta Ecol. Sin. 2020, 3, 10-12. [CrossRef]

51. Li, F.; Kong, Q.; Zhang, Q.; Wang, H.; Luo, T. Spent mushroom substrates affect soil humus composition, microbial biomass and functional diversity in paddy fields. Appl. Soil Ecol. 2020, 149, 103489. [CrossRef]

52. Farooq, M.; Flower, K.C.; Jabran, K.; Wahid, A.; Siddique, K. Crop yield and weed management in rainfed conservation agriculture. Soil Tillage Res. 2011, 117, 172-183. [CrossRef]

53. Marble, S.C.; Koeser, A.K.; Hasing, G. A Review of Weed Control Practices in Landscape Planting Beds: Part II—Chemical Weed Control Methods. Hortscience 2015, 50, 857-862. [CrossRef]

54. Ranaivoson, L.; Naudin, K.; Ripoche, A.; Rabeharisoa, L.; Corbeels, M. Is mulching an efficient way to control weeds? Effects of type and amount of crop residue in rainfed rice based cropping systems in Madagascar. Field Crops Res. 2018, $217,20-31$. [CrossRef]

55. Taak, P.; Koul, B.; Chopra, M.; Sharma, K. Comparative Assessment of Mulching and Herbicide Treatments for Weed Management in Stevia rebaudiana (Bertoni) Cultivation. Available online: https:/ / www.sciencedirect.com/science (accessed on 10 June 2020).

56. Namaghi, M.N.; Davarynejad, G.H.; Ansary, H.; Nemati, H.; Feyzabady, A.Z. Effects of mulching on soil temperature and moisture variations, leaf nutrient status, growth and yield of pistachio trees (Pistacia vera L). Sci. Hortic. 2018, 241, 115-123. [CrossRef]

57. Wang, H.; Wang, C.; Zhao, X.; Wang, F. Mulching increases water-use efficiency of peach production on the rainfed semiarid Loess Plateau of China. Agric. Water Manag. 2015, 154, 20-28. [CrossRef]

58. Chen, Y.; Wen, X.; Sun, Y.; Zhang, J.; Wu, W.; Liao, Y. Mulching practices altered soil bacterial community structure and improved orchard productivity and apple quality after five growing seasons. Sci. Hortic. 2014, 172, 248-257. [CrossRef]

59. Suo, G.D.; Xie, Y.S.; Zhang, Y.; Luo, H. Long-term effects of different surface mulching techniques on soil water and fruit yield in an apple orchard on the Loess Plateau of China. Sci. Hortic. 2019, 246, 643-651. [CrossRef]

60. Jin, S.; Wang, Y.; Shi, L.; Guo, X.; Zhang, J. Effects of pruning and mulching measures on annual soil moisture, yield, and water use efficiency in jujube (Ziziphus jujube Mill.) plantations. Glob. Ecol. Conserv. 2018, 15, e00406. [CrossRef]

61. Basile, B.; Solari, L.I.; Dejong, T.M. Intra-canopy variability of fruit growth rate in peach trees grafted on rootstocks with different vigour-control capacity. J. Hortic. Sci. Biotechnol. 2007, 82, 243-256. [CrossRef] 
62. Dai, Z.; Hu, J.; Fan, J.; Fu, W.; Wang, H.; Hao, M. No-tillage with mulching improves maize yield in dryland farming through regulating soil temperature, water and nitrate-N. Agric. Ecosyst. Environ. 2021, 309, 107228. [CrossRef]

63. Zhang, Y.Q.; Wen, Y.; Bai, Q.; Ma, Z.; Ye, H.L.; Su, S.C. Spatio-temporal effects of canopy microclimate on fruit yield and quality of Sapindus mukorossi Gaertn. Sci. Hortic. 2019, 251, 136-149. [CrossRef]

64. Kar, G.; Kumar, A.; Martha, M. Water use efficiency and crop coefficients of dry season oilseed crops. Agric. Water Manag. 2007, 87, 73-82. [CrossRef] 